\title{
Detailed modelling of biomass steam gasification in a dual fluidized bed gasifier with temperature variation
}

Aghaalikhani, Arash; Schmid, Johannes C.; Borello, Domenico; Fuchs, Joseph; Benedikt, Florian; Hofbauer, Herman; Rispoli, Franco; Henriksen, Ulrick B.; Sárossy, Zsuzsa; Cedola, Luca

\section{Published in:}

Renewable Energy

Link to article, DOI:

10.1016/j.renene.2019.05.022

Publication date:

2019

Document Version

Peer reviewed version

Link back to DTU Orbit

Citation $(A P A)$ :

Aghaalikhani, A., Schmid, J. C., Borello, D., Fuchs, J., Benedikt, F., Hofbauer, H., Rispoli, F., Henriksen, U. B., Sárossy, Z., \& Cedola, L. (2019). Detailed modelling of biomass steam gasification in a dual fluidized bed gasifier with temperature variation. Renewable Energy, 143, 703-718.

https://doi.org/10.1016/j.renene.2019.05.022

\section{General rights}

Copyright and moral rights for the publications made accessible in the public portal are retained by the authors and/or other copyright owners and it is a condition of accessing publications that users recognise and abide by the legal requirements associated with these rights.

- Users may download and print one copy of any publication from the public portal for the purpose of private study or research.

- You may not further distribute the material or use it for any profit-making activity or commercial gain

- You may freely distribute the URL identifying the publication in the public portal 
See discussions, stats, and author profiles for this publication at: https://www.researchgate.net/publication/330912795

Detailed modelling of biomass steam gasification with a dual fluidized bed gasifier - validation by experimental data from temperature variation

Conference Paper · September 2018

CITATIONS

0

9 authors, including:

9. Arash Aghaalikhani

Sapienza University of Rome

4 PUBLICATIONS 8 CITATIONS

SEE PROFILE

D. Borello

Sapienza University of Rome

113 PUBLICATIONS 1,109 CITATIONS

SEE PROFILE
READS

65

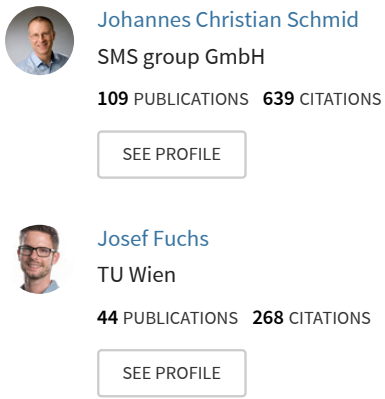

Some of the authors of this publication are also working on these related projects:

Turbine Blade Cooling View project 


\title{
Detailed modelling of biomass steam gasification with a dual fluidized bed gasifier - validation by experimental data from temperature variation
}

\author{
A. Aghaalikhani ${ }^{* 1,2}$, J.C. Schmid ${ }^{1}$, D. Borello ${ }^{3}$, J. Fuchs ${ }^{1}$, F. Benedikt ${ }^{1}$, \\ H. Hofbauer ${ }^{1}$, F. Rispoli ${ }^{3}$, U. B. Henriksen ${ }^{4}$, Z. Sárossy ${ }^{4}$ \\ ${ }^{1}$ Institute of Chemical, Environment and Bioscience Engineering, \\ Vienna University of Technology, Vienna, Austria \\ ${ }^{2}$ Dipartimento di Ingegneria Astronautica, Elettrica ed Energetica \\ La Sapienza University of Rome, Rome, Italy \\ ${ }^{3}$ Dipartimento di Ingegneria Meccanica e Aerospaziale, \\ La Sapienza University of Rome, Rome, Italy \\ ${ }^{4}$ Department of Chemical and Biochemical Engineering \\ Technical University of Denmark, Roskilde, Denmark \\ *Corresponding author: e-mail: arash.aghaalikhani@uniroma1.it
}

\begin{abstract}
Biomass energy conversion is a reliable way to produce energy and chemical products if compared with other renewable sources such as wind, solar and wave which have intermittent nature. Amongst different methods of converting biomass to energy, the thermo-chemical process of steam gasification is an outstanding way, since it enables a subsequent polygeneration process that can lead to production of heat, electricity, synthetic natural gas and synthetic chemicals such as methanol, Fischer-Tropsch diesel, gasoline and kerosene.

The modelling of biomass gasification enables the optimization of the process designs, but it is a challenge due to its high complexity. Here, a new approach is used to simulate a $100 \mathrm{~kW}$ dual fluidized bed gasifier. Detailed pyrolysis modelling is a key factor of this approach and enables more accurate results. The results have been validated by experiments conducted with softwood pellets as fuel and fresh olivine sand as bed material. The impact of the gasifier temperature variation on the final product gas composition is measured in the experiments and implemented in the simulation to have a better insight on the pyrolysis process, the char heterogeneous reactions as well as the deviation from equilibrium of the water gas-shift reaction.
\end{abstract}

\section{KEYWORDS}

Renewable energy, Biomass, Thermo-chemical conversion, Gasification, Dual Fluidized bed

\section{INTRODUCTION}

The thermo-chemical conversion of biomass is an environmental-friendly and efficient way of producing heat and power, as well as green hydrogen, synthetic natural gas (methane) and liquid chemicals. Biomass is abundant in nature and is the only carbon source within the range of renewable resources. Amongst different technologies developed for thermo-chemical conversion of biomass, dual fluidized bed steam gasification is applied by preference since the generation of a nitrogen-free product gas is possible. The medium calorific gas is predestined for the use as synthetic gas for the production of renewable chemicals. This technology

*Arash Aghaalikhani (arash.aghaalikhani@uniroma1.it) 
promotes the conversion of solid feedstock (biomass, residues and waste materials) into a valuable gas rich in hydrogen with an excellent gas-solid contact and heat transfer, offering a very homogenous temperature distribution in the reactor. The fluidized bed (FB) technology is also highly qualified for 'scale up' and the technical feasibility of this gasification technology has been proven with the combined heat and power plants across Europe [1,2].

In this study, a series of experimental tests have been conducted on the dual fluidized bed at TU Wien by varying the temperature aiming at assessing its impact on the final producer gas. Finally, a detailed model is developed in ASPEN plus to simulate the gasification process and it was validated against the experimental results.

The basic assumption in most cases is to introduce biomass as its constituent elements (CHNO) which results in inaccurate predications and cannot explain the reactions occurring during the gasification. A review of gasification modelling [3] shows that this basic assumption was adopted in most cases.

There have been also few attempts to introduce the pyrolysis reactions in ASPEN plus with an empirical correlation between the yield of the products and the temperature of the process [4]. When we tried to replicate such correlation, it was noticed that the yields of the products are negative at some temperatures, and in many other cases the pyrolysis products and the biomass do not satisfy the mass balance.

Here, the pyrolysis model based on circa 300 hundred different fast/intermediate pyrolysis experiments of woody biomass [5] is implemented in the ASPEN plus flowsheet. For some of the product yields, imperical correlations have been found with coefficient of correlation close to 1 , and the amount of the rest of the products are obtained by mass and energy balance calculation as described with more detail in the next chapters.

\section{EXPERIMENTAL SETUP}

\section{Process description}

The $100 \mathrm{~kW}$ pilot plant at TU Wien is a modified version of the dual fluidized bed gasifier (DFB) of Gussing [6]. In principle, the DFB gasifier divides the gasification and combustion reactions in two separate reactors, where the combustor provides the necessary heat for the overall endothermic reactions through the circulation of the hot bed material. The residual char after the gasification is transported to the combustor and is burnt to heat up the bed material. The fluidization agent in the gasifier is steam, which results to a nearly nitrogen-free product gas which mainly consists of $\mathrm{H}_{2}$, $\mathrm{CO}, \mathrm{CO}_{2}, \mathrm{CH}_{4}$ and $\mathrm{C}_{2} \mathrm{H}_{4}$ with a lower heating value of about $12-15 \mathrm{MJ} / \mathrm{Nm}^{3}$ [7].

In the improved design of the plant, some constraints are introduced in the gasifier column to capture some of the bed material for the enhancement of in-situ conversion of hydrocarbons. Figure 1 shows the basic principle of the plant and in Figure 2 the novel DFB design can be seen [8]. 


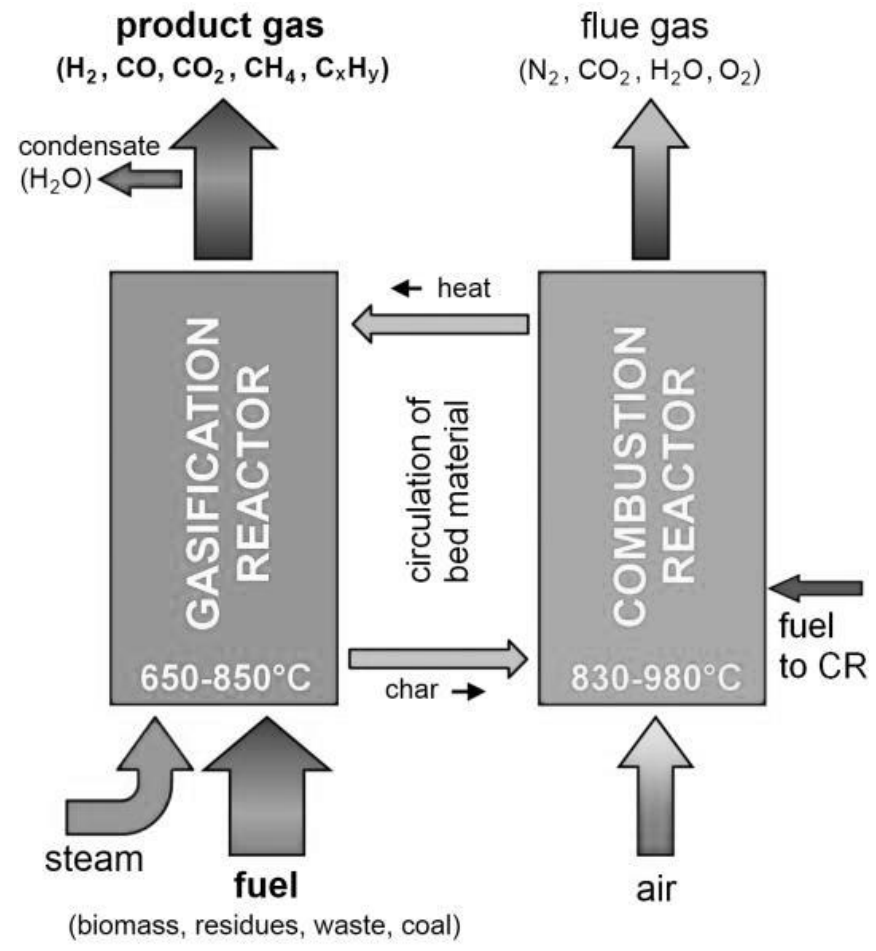

Figure 1 Basic principle of circulating dual fluidized bed

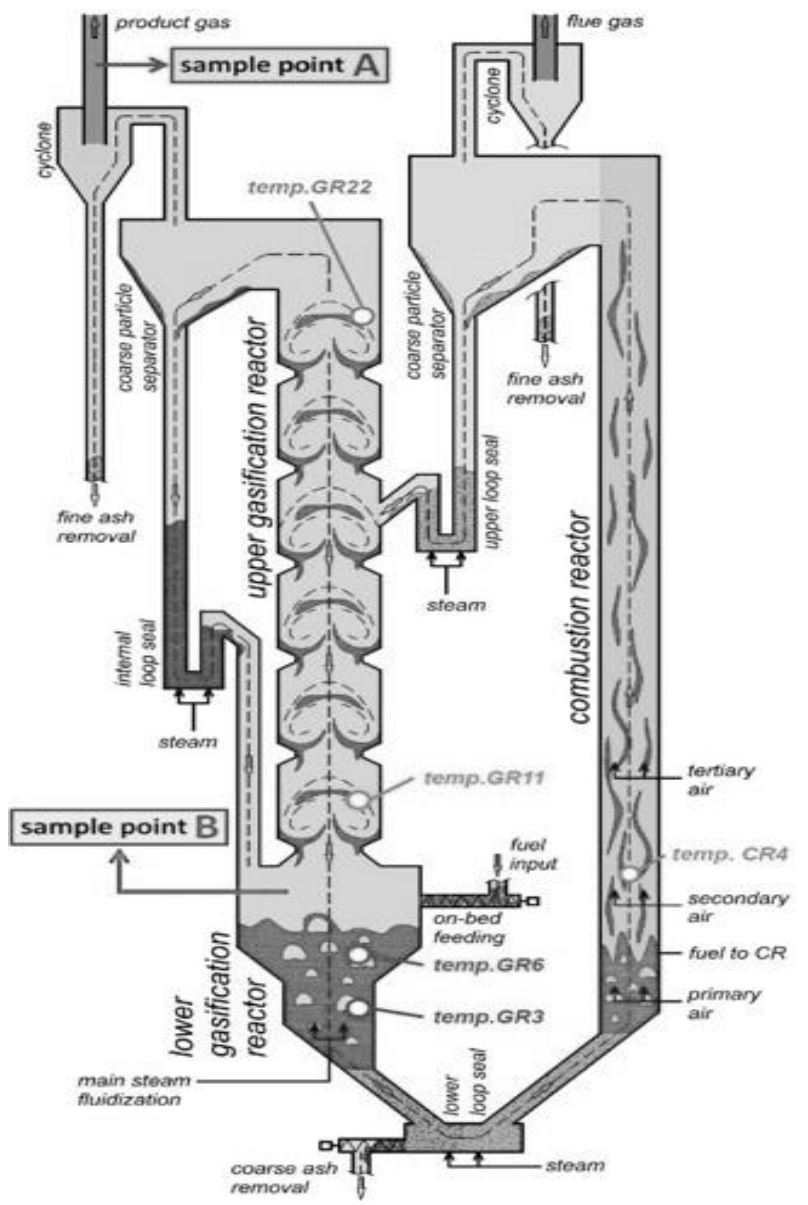

Figure 2 The novel DFB design of TUW [8] 


\section{Feedstock characterization}

The biomass feedstock used in this study is softwood pellets since it represents standard fuel of gasification and has a very low amount of ash, which prevents agglomeration as well as catalytic effect of some alkaline compounds in the ash. The biomass feedstock has been characterized before its use in the gasifier. The following analysis were carried-out: humidity, to calculate the water content in the biomass as used; $\mathrm{CHNS}$ and $\mathrm{Cl}$ analysis; elemental ash analysis by means of $\mathrm{XRF}$, to obtain the quantity of the metals and alkali metals contained in the ash; and proximate analysis to obtain the amount of fixed carbon in the biomass as well as the volatiles. A summary of the results is shown in the Table 1.

Table 1. Characterization of the feedstock

\begin{tabular}{|c|c|c|c|c|c|c|c|}
\hline \multicolumn{2}{|c|}{ Source of fuel Parameter } & \multicolumn{6}{|c|}{$\begin{array}{l}\text { TU Wien Test Laboratory } \\
\text { "Softwood pellets" }\end{array}$} \\
\hline \multicolumn{3}{|c|}{ General } & \multicolumn{3}{|c|}{ Elemental composition } & \multicolumn{2}{|c|}{$\begin{array}{l}\text { Ash analysis (wt.- } \\
\% \mathrm{db})\end{array}$} \\
\hline \multirow[t]{4}{*}{ Water content } & \multirow[t]{4}{*}{ wt.-\% } & \multirow[t]{4}{*}{7.2} & \multirow[t]{2}{*}{ Ash content } & \multirow{2}{*}{$\begin{array}{l}\text { wt.- } \\
\% \mathrm{db}\end{array}$} & \multirow[t]{2}{*}{0.2} & $\mathrm{SiO} 2$ & 6.62 \\
\hline & & & & & & $\mathrm{Al} 2 \mathrm{O} 3$ & 1.63 \\
\hline & & & \multirow[t]{2}{*}{ Carbon $(\mathrm{C})$} & \multirow{2}{*}{$\begin{array}{l}\text { wt.- } \\
\% \mathrm{db}\end{array}$} & \multirow[t]{2}{*}{50.7} & $\mathrm{CaO}$ & 55.2 \\
\hline & & & & & & $\mathrm{Fe} 2 \mathrm{O} 3$ & 0.91 \\
\hline \multirow[t]{2}{*}{ Volatiles } & \multirow[t]{2}{*}{ wt.-\%db } & \multirow[t]{2}{*}{85.4} & \multirow{2}{*}{$\begin{array}{l}\text { Hydrogen } \\
(\mathrm{H})\end{array}$} & \multirow{2}{*}{$\begin{array}{l}\text { wt.- } \\
\% \mathrm{db}\end{array}$} & \multirow[t]{2}{*}{5.9} & $\mathrm{~K} 2 \mathrm{O}$ & 13.4 \\
\hline & & & & & & $\mathrm{Na} 2 \mathrm{O}$ & 1.07 \\
\hline \multirow{2}{*}{$\begin{array}{l}\text { Residual char } \\
\text { (incl. ash) }\end{array}$} & \multirow[t]{2}{*}{ wt.-\%db } & \multirow[t]{2}{*}{14.6} & Oxygen $(\mathrm{O})$ & wt.- & 43.0 & $\mathrm{MgO}$ & 8.35 \\
\hline & & & Nitrogen $(\mathrm{N})$ & wt.- & 0.2 & $\mathrm{P} 2 \mathrm{O} 5$ & 3.07 \\
\hline LHV (dry) & $\mathrm{MJ} / \mathrm{kgdb}$ & 18.9 & Sulphur (S) & wt.- & 0.005 & $\mathrm{TiO} 2$ & 0.12 \\
\hline LHV (moist) & $\mathrm{MJ} / \mathrm{kg}$ & 17.4 & Chlorine $(\mathrm{Cl})$ & wt.- & 0.005 & $\mathrm{MnO}$ & 5.44 \\
\hline \multicolumn{3}{|c|}{ Ash melting behavior } & \multicolumn{3}{|c|}{ Deformation temperature (A) } & \multicolumn{2}{|c|}{1335} \\
\hline
\end{tabular}

\section{Bed material}

The bed material used in this investigation is olivine because of its high catalytic activity and high resistance to attrition. The olivine is sieved to have particle size in the range of 100 to 300 microns, resulting the Sauter mean diameter $\mathrm{d}_{\mathrm{sv}}$ of $0.25 \mathrm{~mm}$, and the input flow rate of the steam is calculated to maintain the fluidization of the bed material in the bubbling phase of the gasification reactor, and the air flow rate is set to create a fast fluidization state in the combustion reactor. Table 2 summaries the characteristics of the bed material.

Table 2 Characterization of the bed material

\begin{tabular}{|c|c|c|}
\hline parameter & unit & value \\
\hline $\mathrm{MgO}$ & wt.-\% & $48-50$ \\
\hline $\mathrm{SiO}_{2}$ & wt.-\% & $39-42$ \\
\hline $\mathrm{Fe}_{2} \mathrm{O}_{3}$ & wt.-\% & $8.0-10.5$ \\
\hline $\mathrm{Al}_{2} \mathrm{O}_{3}+\mathrm{Cr}_{2} \mathrm{O}_{3}+\mathrm{Mg}_{3} \mathrm{O}_{4}$ & wt.-\% & $0.7-0.9$ \\
\hline $\mathrm{CaO}$ & wt.-\% & $<0.4$ \\
\hline $\mathrm{NiO}$ & wt.-\% & $<0.1$ \\
\hline $\mathrm{CaCO} 3$ & wt.-\% & $<0.1$ \\
\hline Trace elements & wt.-\% & $<0.1$ \\
\hline Hardness & Mohs & $6-7$ \\
\hline Particle density & kg/m3 & $\approx 2850$ \\
\hline
\end{tabular}




\section{Operational condition}

To assess the effect of temperature variation on the product syngas composition of gasification, the temperature of the bubbling bed is varied from 650 to $900{ }^{\circ} \mathrm{C}$. in Figure 2 this temperature is referred as GR6 and the position of the sensor that measures it is shown. The combustor temperature (CR4) is controlled via the introduction of additional fuel into the combustion reactor. Thus, the desired GR6 temperature in the gasification reactor is adjusted to the prefixed value. In the test runs, 70-90 kg of fresh olivine sand is used as bed material. The softwood pellets are fed to the gasification reactor onto the bubbling bed. The pellet mass flow ranges between 19.4 and $21.3 \mathrm{~kg} / \mathrm{h}$ corresponding to a thermal power of $97-103 \mathrm{~kW}$. The typical heat loss of the system is measured to be in the range of $24-29 \mathrm{~kW}$ and it is neglected in the simulation. Thus, the additional fuel input to the CR is always lower in the model as in the experiments.

\section{Measurements}

More than 200 sensors are implemented in the plant to measure temperature and pressure in various points of the plant, air, steam and fuel flows as well as the gas composition of the produced gas and the flue gas. Table 3 presents the typology and the number of available measurement devices of the pilot plant. More detailed description is available in [6]. Additionally, $\mathrm{CH}_{4}, \mathrm{C}_{2} \mathrm{H}_{4}$, $\mathrm{C}_{2} \mathrm{H}_{6}, \mathrm{CO}$ and $\mathrm{CO}_{2}$ were analysed every 15 minutes by a gas chromatograph (Perkin Elmer ARNEL - Clarus 500). An adapted standardized arrangement of sampling equipment was used to analyse the content of dust, char and gravimetric tar in the product gas. An extensive overview of the advance DFB plant of TU Wien is available in [9].

Table 3 Typology and number of measuring devices

\begin{tabular}{|c|c|c|}
\hline Parameter & Device or principle & Number \\
\hline Temperature & Thermocouple (type K) & $>100$ \\
\hline Pressure & Pressure sensor (Kalinsky DS2) & $>70$ \\
\hline Main air and steam flows & Krohne (float-type or vortex) & 8 \\
\hline Fuel input & Scales & 3 \\
\hline Main gas composition & Rosemount NGA 2000 & 12 \\
\hline
\end{tabular}

Besides the measurements at TU Wien, a thermogravimetric analyser (TGA) in the laboratory of Technical University of Denmark (DTU) has been used to investigate the char reactivity with steam and carbon dioxide.

\section{Mass and energy balance (IPSEpro)}

The software package IPSEpro is used for evaluation and validation of the process data, which were gathered during the experiments. Mass and energy balance is computed for every single experimental test run (per gasification temperature) with this tool. IPSEpro is a software package originating from the power plant sector, which offers stationary process simulations based on flow sheet handling. The software uses an equation-oriented solver. To validate the measured data, a 
mass and energy balance is used. IPSEpro is minimizing the general error from measurement values to a minimum [10].

\section{MODEL DEVELOPMENT}

Simulating the process of gasification in dual fluidized bed (DFB) gasifiers is very challenging, due to various reactions occurring in parallel and interacting with each other. Here a new method is developed in ASPEN plus simulator on the basis of the experimental data set. The aim is to tune the model with experiments to obtain a better prediction of the gas composition and a better insight on char reactivity in DFB gasifier. In ASPEN plus simulator, biomass can be defined as a nonconventional heterogenous compound, being described with its ultimate, proximate and sulphur analysis. Although ASPEN plus is capable of handling solid materials, this is not possible when they have heterogenous structure. Therefore, the model has to turn into either constituent elements or product yields after devolatilization. The assumption that the biomass turns into its constituent elements $(\mathrm{CHON})$ will lead to very unrealistic results, since it not only cannot take into account the temperature effect on the pyrolysis yields, but it cannot either represent the chemical bounds in the biomass either. Here, the proposed model considers a separation between parallel reactions in the gasifier trying to represent them in a realistic way on the basis of experimental data. In the DFB gasifier the biomass is inserted on top of the bubbling bed at a temperature typically around $800{ }^{\circ} \mathrm{C}$, then it will be dried, the moisture content will evaporate and rise in the freeboard of the gasifier. Dried biomass will go through devolatilization and the volatiles will leave, and the char will remain to react with the gases. The unconverted char will be dragged by the bed material to the combustor via a loop to be burned there and provide the necessary heat needed for the overall endothermic reactions in the gasification reactor (GR). The important reactions in GR are listed in Table 4.

Table 4 Main reactions in the gasification reactor [11]

\begin{tabular}{|c|c|c|c|c|}
\hline \multicolumn{3}{|c|}{ Reactions } & $\begin{array}{c}\Delta \mathrm{H}\left(850^{\circ} \mathrm{C}\right) \\
{[\mathrm{kJ} / \mathrm{kmol}]}\end{array}$ & $\begin{array}{c}\Delta \mathrm{G}\left(850{ }^{\circ} \mathrm{C}\right) \\
{[\mathrm{kJ} / \mathrm{kmol}]}\end{array}$ \\
\hline 1 & Char steam gasification & $\mathrm{C}+\mathrm{H}_{2} \mathrm{O} \rightarrow \mathrm{CO}+\mathrm{H}_{2}$ & 135.8 & -25.4 \\
\hline 2 & Buodouard & $\mathrm{C}+\mathrm{CO}_{2} \rightarrow 2 \mathrm{CO}$ & 169.8 & -26.2 \\
\hline 3 & Char reaction with $\mathrm{H}_{2}$ & $\mathrm{C}+2 \mathrm{H}_{2} \rightarrow \mathrm{CH}_{4}$ & -91.0 & 33.1 \\
\hline 4 & Water-gas shift & $\mathrm{CO}+\mathrm{H}_{2} \mathrm{O} \rightarrow \mathrm{CO} 2+\mathrm{H}_{2}$ & -34.0 & 0.9 \\
\hline 5 & Steam reforming & $\mathrm{CH}_{4}+\mathrm{H}_{2} \mathrm{O} \rightarrow \mathrm{CO}+3 \mathrm{H}_{2}$ & +226.6 & -58.3 \\
\hline
\end{tabular}

These reactions have different kinetics, and this is especially evident between the heterogenous $(1,2,3)$ and the homogenous $(4,5)$ reactions. The heterogeneous reactions of char with gas are much slower than gas-gas reactions [11]. 


\section{Modelling assumptions}

Several assumptions are made when developing the model aiming at obtaining accurate prediction at a reduced computational cost:

- The amount of nitrogen, sulphur and chlorine in the biomass is neglected. In fact, their amount is less than $0.2 \%$ of the biomass.

- Drying and devolatilization occur instantaneously.

- Amongst the cited homogenous reactions only water-gas shift reaction has the dominant effect for hydrogen production [13].

- The char is assumed to be pure carbon. In fact, the carbon content in the char in the simulated temperature range is between 85 and $95 \%$.

- A restricted equilibrium is considered by tuning the char conversion rate and the fractional conversion of CO in WGSR. The coefficients are validated either by the literature or the experiments.

- Tar is also considered, and it is represented as four lumped primary and secondary groups (Levoglucosan " $\mathrm{C}_{6} \mathrm{H}_{10} \mathrm{O}_{5}$ ", Hydroxyacetaldehyde " $\mathrm{C}_{2} \mathrm{H}_{4} \mathrm{O}_{2}$ ", Furfural " $\mathrm{C}_{5} \mathrm{H}_{4} \mathrm{O}_{2}$ " and Phenol " $\mathrm{C}_{6} \mathrm{H}_{5} \mathrm{OH}$ ") [14].

- The tar is cracked either thermally or are reformed with steam (dry reforming is neglected).

- Heat losses are not considered in the model.

\section{Drying}

When biomass is fed into the gasifier, the free water evaporates. Although biomass (wood pellets) drying is not normally considered as a chemical reaction, a stoichiometric block was used in ASPEN plus to convert a part of the biomass to form water. The following equation represents the drying process for the initial softwood pellets:

$$
\text { Biomass (wet) } \rightarrow 0.0555084 \mathrm{H}_{2} \mathrm{O}+\text { Biomass (dry) }
$$

ASPEN plus treats all nonconventional components as if they have a molecular weight of 1 . The reaction indicates that 1 mole of biomass reacts to form 0.0555084 mole of water which corresponds to the water content of the biomass. The conversion for this reaction must be set to achieve the proper amount of drying. At code start-up, the fractional conversion is set to be 0.2 but its value is later overridden by using a calculator box.

\section{Pyrolysis}

After being dried, the model arranges the decomposition of biomass through the pyrolysis process, turning into char $\left(\mathrm{C}_{\mathrm{x}} \mathrm{H}_{\mathrm{y}} \mathrm{O}_{\mathrm{z}}\right)$, volatiles $\left(\mathrm{CO}, \mathrm{CO}_{2}, \mathrm{CH}_{4}, \mathrm{C}_{\mathrm{x}} \mathrm{H}_{\mathrm{y}}, \mathrm{H}_{2}\right)$, non-condensable gases tar and pyrolytic water $\left(\mathrm{H}_{2} \mathrm{O}\right)$. The water arises from several pyrolysis reactions and is chemically bound in the biomass. The mechanism and the yields of products of this process are shown in Figure 3 [5]: 


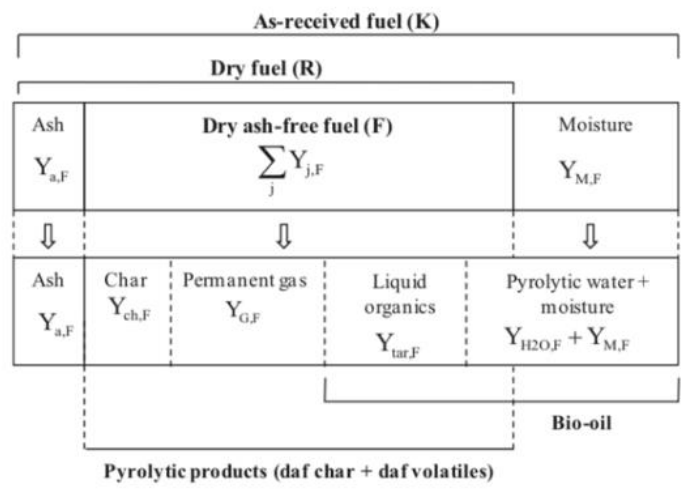

Figure 3 Overall mass balance to the biomass pyrolysis process. The quantities presented in each box are mass ratios (Y) referred to the dry ash-free part of fuel (subscript "F"), $\mathrm{kg} / \mathrm{kg}$ daf fuel. The length of each box is only illustrative. Adopted from [5]

Modelling this process is the most challenging task in a biomass gasification simulation and, for such reason, it is neglected in many other works [3] pertinent to biomass gasification, where the biomass is assumed to yield to its constituent elements of $\mathrm{CHNO}$, eventually leading to inaccurate results.

When both stoichiometry and kinetics of the process are not known, the best way to define the reaction in ASPEN plus is to use RYield block. This block requires the known yields of the products in either mass or mole basis. The true yields of the components after pyrolysis depends however on many variables such as the temperature of the reactor, the heating rate, the particles size, the residence time and the amount of fuel [15]. An attempt to find the empirical correlations between the yield of the components and the temperature was done by Neves et al [5] using about 300 different experimental investigation on the process. The investigations were classified in fast and slow pyrolysis. Since in the DFB gasifier at TU Wien, the pyrolysis happens in less than few seconds, only the correlations for the fast pyrolysis are considered. According to this research, there are correlations between the yields of $\mathrm{CH}_{4}$ and $\mathrm{CO}[16,17$,$] , between the yields of \mathrm{H}_{2}$ and $\mathrm{CO}$ and the yield of $\mathrm{H}_{2}$ as a function of pyrolysis peak temperature $[18,19]$, yield of Char and its elemental composition as a function of pyrolysis peak temperature [20,2122], elemental composition of the Tars [22,23], and the lower heating value in the function of temperature [24,25]. For the mentioned empirical correlations, the coefficient of the determination " $\mathrm{R}$ " " is always high enough to be taken as a reference for the further calculations. The adopted formulas are reported below:

$$
\begin{gathered}
Y_{\text {char }, F}=0.106+2.43 \exp \left(-0.66 .10^{-2} . T\right) \\
Y_{H_{2}, F}=1.145\left(1-\exp \left(-0.11 \cdot 10^{-2} . T\right)^{9.384}\right. \\
Y_{H_{2}, F} /_{Y_{C O, F}}=3.10^{-4}+\frac{0.0429}{1+(1+T / 632)^{-7.23}} \\
Y_{C H_{4}, F}=-2.18 .10^{-4}+0.146 . Y_{C O, F} \\
L H V_{G}=-6.23+2.47 .10^{-2} . T
\end{gathered}
$$

Even though there was the alternative of experimentally assessing the pyrolysis yields for the softwood pellets used in the test runs, this method was avoided, because the results would be more accurate but in a very narrow spectra of feedstock variations. To build a more robust model, it is assumed to minimize the uncertainties, so the model will work reasonably well in more scenarios, instead of very well in only a few. All the yields are on mass basis from the dried ash free biomass since the mass is a conservative value. In Figure 4, the char composition as function of peak temperature is shown $[26,27,28]$. It contains mostly $\mathrm{C}(85-95 \%)$ with a small amount of $\mathrm{H}$ and $\mathrm{O}$. 


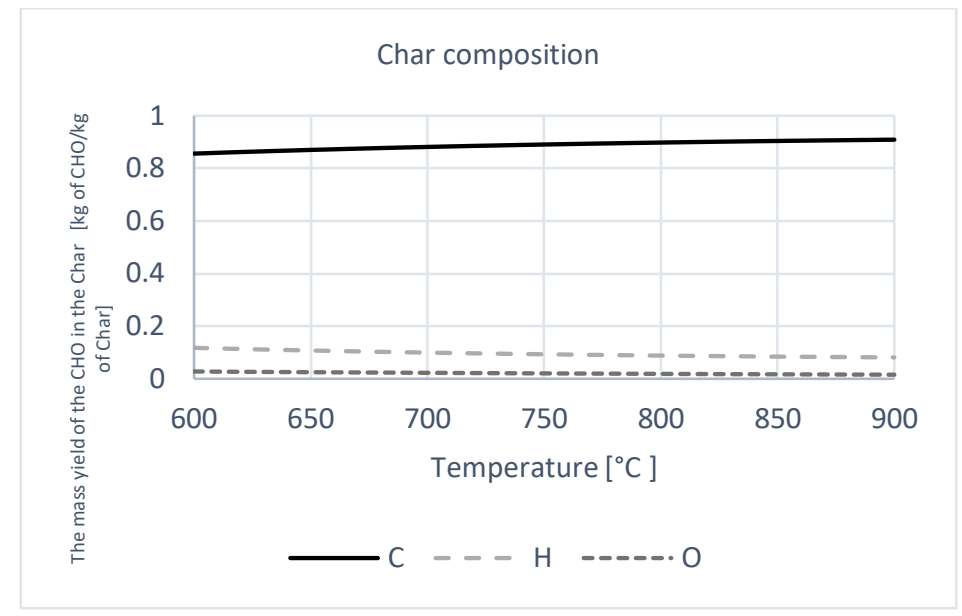

Figure 4 Elemental composition of the Char as a function of the peak temperature of pyrolysis

Therefore, to overcome the cited limitation of ASPEN plus, it was decided to model the Char as pure carbon (homogeneous compound) instead of a heterogeneous nonconventional compound in the simulation (see the modelling assumptions cited before).

The same type of correlation exists also for the $\mathrm{CHO}$ content in the tar [17,18]. Contrasting with the behaviour of char, there is a weak relationship between the elemental composition of tar and pyrolysis temperature. This further suggests averaging all the data available and obtaining the following correlations:

$$
\begin{aligned}
& Y_{r+a r} / Y_{r F}=1.16 \\
& Y_{n+a r} / Y_{\text {OF }}=0.81 \\
& Y_{H+a r} / Y_{H F}=1.1 !
\end{aligned}
$$

Now, it is possible to write the atom balance and energy balance for the pyrolysis products. A system of linear equations with 4 equations (atom balance $\mathrm{CHO}$, energy balance) is obtained and the yields of other four components $\left(\mathrm{CO}_{2}, \mathrm{C}_{\mathrm{x}} \mathrm{H}_{\mathrm{y}}, \mathrm{H}_{2} \mathrm{O}\right.$, TAR) can be calculated. Furthermore, analysing the literature results [29], one can notice that the amount of $\mathrm{C}_{2} \mathrm{H}_{6}$ is negligible. Therefore for the modelling of other light hydrocarbons $\left(\mathrm{C}_{\mathrm{x}} \mathrm{H}_{\mathrm{y}}\right)$, only Ethylene $\left(\mathrm{C}_{2} \mathrm{H}_{4}\right)$ is considered here. The atom balances and energy balance equations are reported below:

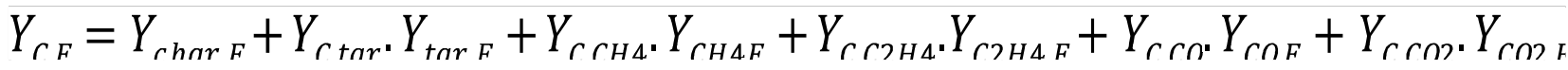

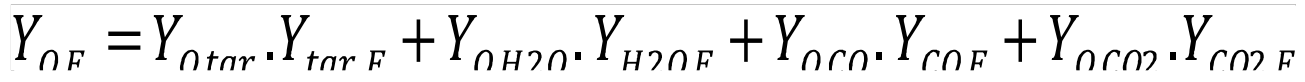

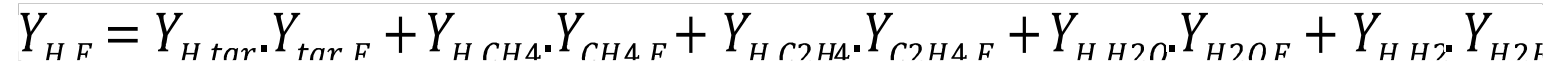

$$
\begin{aligned}
& \left(\sum_{i} Y_{j, F}-Y_{c h a r, F} \cdot \sum_{i} Y_{j, c h}\right) \cdot L H V_{G}=\left(Y_{t a r, F}+Y_{H 2 O, F}\right) \cdot L H V_{G}+Y_{C 2 H 4, F} \cdot L H V_{C 2 H 4}+Y_{C H 4, F} \cdot L H V_{C H 4}+Y_{C O, F} \cdot L H V_{C O}+Y_{H 2, F} \cdot L H V_{H z}
\end{aligned}
$$

The results of these calculations are reported in the Figure 5 and Figure 6: 


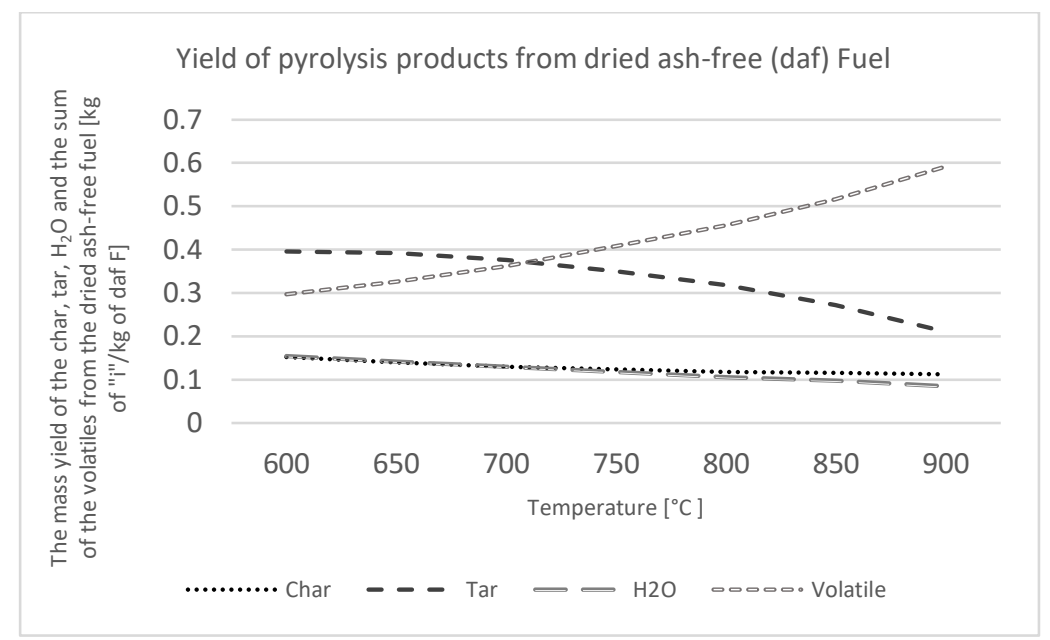

Figure 5 Yields of dried ash-free char $\left(Y_{\mathrm{ch}, \mathrm{F}}\right)$, total pyrolytic gas $\left(\mathrm{Y}_{\mathrm{G}, \mathrm{F}}\right)$, yield of $\operatorname{tar}\left(\mathrm{Y}_{\mathrm{tar}, \mathrm{F}}\right)$ and pyrolytic water $\left(\mathbf{Y}_{\mathrm{H} 2 \mathrm{O}, \mathrm{F}}\right)$ as a function of pyrolysis peak temperature.

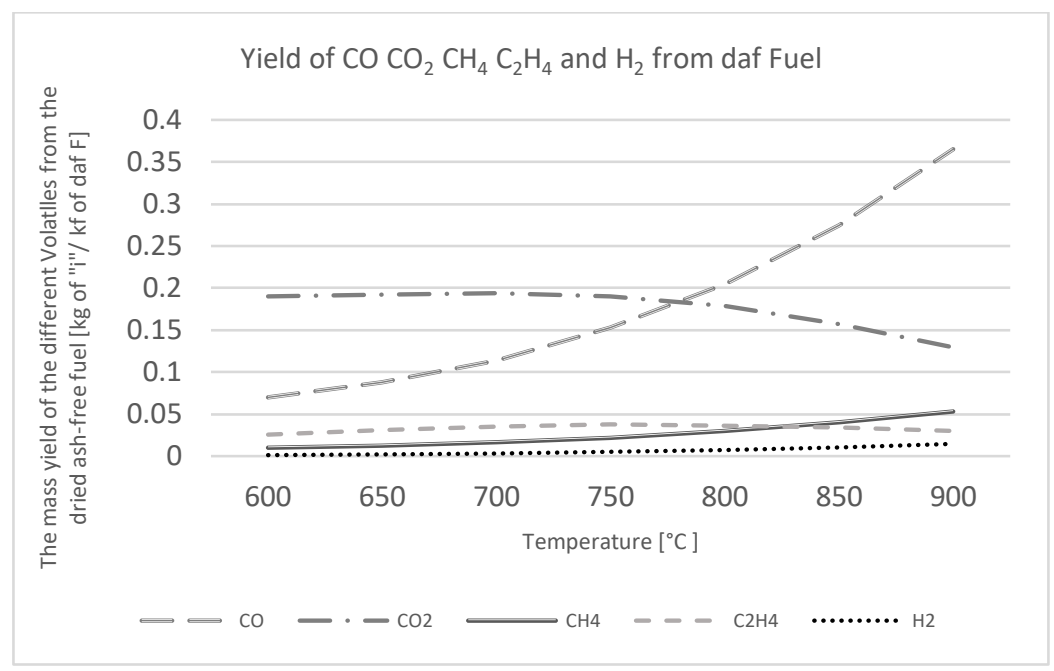

Figure 6 Composition of pyrolysis gas (mass fractions) as a function of peak temperature as given by empirical model and (mass \% of daf fuel)

The temperature below $600{ }^{\circ} \mathrm{C}$ is not considered here, since literature shows [30] that below this temperature some tar remains as residue in the char thus affecting the model predictions. Above all, this is not a typical operational condition for the DFB gasifier. As one can observe from these results, when increasing the temperature, the amount of $\mathrm{CO}$ is rising, and the amount of $\mathrm{CO}_{2}$ is decreasing. Considering the water gas shift reaction as the most important reaction in the process, and assuming that the provided steam is always enough for this reaction, in steam gasification, when increasing the temperature, the rise of $\mathrm{CO}_{2}$ and decreasing of $\mathrm{CO}$ is expected. Then, the nonconventional heterogeneous biomass is transformed to all conventional components except for the tar.

\section{Tar}

Some authors neglect the tar contribution in the simulation of the DFB gasifier because of the modelling complexity $[4,40]$. The tars amount at the outlet of the DFB gasifiers are very low and usually in the range of few milligrams to few grams per normal cubic meter of gas. However, the tars formed after the pyrolysis in general are not negligible. As it can be seen in the Figure 5, the 
yield of tars in the temperature range of $600-900{ }^{\circ} \mathrm{C}$ ranges between $40-20 \%$ of the dried-ash free fuel on mass basis. According to tar classification of Milne et al. [14], at different temperatures different tar groups are formed. Tar distribution depending on temperature is summarized below:

- Class 1 of tar consists of cellulose-derived products such as levoglucosan, hydroxyacetaldehyde and furfurals as well as products originating from hemicellulose constituents and lignin-derived methoxyphenols. These primary pyrolysis products appear at $500^{\circ} \mathrm{C}$. Their quantity reduces when temperature increases, and they are virtually absent above $800^{\circ} \mathrm{C}$.

- Secondary tar (class 2) are phenolics and olefins. They are present in the temperature range $500-1000^{\circ} \mathrm{C}$.

- Tertiary tar (class 3) include methyl derivatives of aromatics such as methyl acenaphthylene, methylnaphthalene, toluene and indene are formed in the temperature range of $650^{\circ} \mathrm{C}$ to more than $1000^{\circ} \mathrm{C}$.

- The fourth class is the aromatics without substituents (tertiary-PNA) such as benzene, naphthalene, acenaphthylene, anthracene/phenanthrene and pyrene and they are formed above $750^{\circ} \mathrm{C}$.

In the developed model, the amount of tars for different temperatures, and their composition in a correlation with ultimate analysis of the biomass is assumed. Therefore, a simple algorithm was developed of an under-determined system of equations, based on the previous calculations, to calculate the sum of different tar groups corresponding to the amount of tar and its composition after pyrolysis. The tar groups were lumped in 2 classes and 4 groups of the primary and secondary products only. They are pyrolysis oils (levoglucosan $\mathrm{C}_{6} \mathrm{H}_{10} \mathrm{O}_{5}$, hydroxyacetaldehyde $\mathrm{C}_{2} \mathrm{H}_{4} \mathrm{O}_{2}$, furfural $\mathrm{C}_{5} \mathrm{H}_{4} \mathrm{O}_{2}$ ) as primary tars, and secondary tars (phenol $\mathrm{C}_{6} \mathrm{H}_{5} \mathrm{OH}$ ). This assumption can be valid, since all the tars are assumed to be either cracked thermally or reformed with steam in an equilibrium reactor.

In Figure 7 the yield of different tar groups with the temperature is shown:

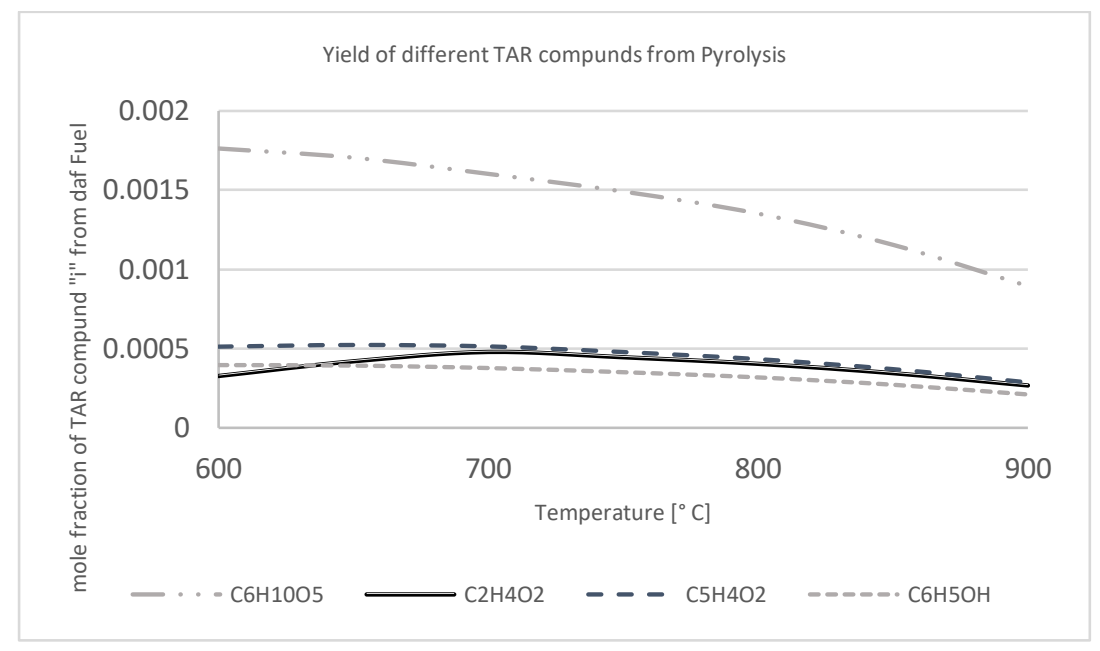

Figure 7 Yield of different tar compounds after pyrolysis as a function of peak temperature

\section{Char gasification}

The solid residual of the biomass after devolatilization, namely char, will go through the bubbling bed of the GR and will be transported with the bed material to the CR where it is burnt. During its passage, a char fraction reacts with other gases such as steam, $\mathrm{CO}_{2}$ and $\mathrm{H}_{2}$ with different reaction rates. The reaction with steam is much faster than that with $\mathrm{CO}_{2}$ and $\mathrm{H} 2$ 
but still many times slower than gas-gas reactions [32]. Since the kinetics of these reactions are slow and the residence time is limited to the circulation rate of the bed material, a high conversion rate is not expected. The reactions are reported below:

$$
\begin{gathered}
\mathrm{C}(\text { solid })+\mathrm{H}_{2} \mathrm{O} \text { (gas) } \rightarrow \mathrm{CO} \text { (gas) }+\mathrm{H}_{2} \text { (gas) } \\
\mathrm{C}(\text { solid })+2 \mathrm{H}_{2} \text { (gas) } \rightarrow \mathrm{CH}_{4} \text { (gas) } \\
\mathrm{C}\left(\text { solid) }+\mathrm{CO}_{2} \text { (gas) } \rightarrow 2 \mathrm{CO}\right. \text { (gas) }
\end{gathered}
$$

The measurement of char conversion cannot be done directly inside the plant under experimental investigation, and in the literature reaction kinetics show great differences in terms of the activation energy and frequency number from different findings by various authors [33].

In this work, after separating all the main reactions in the simulation, the reactivity of char with the $\mathrm{CO}_{2}$ and steam have been investigated with thermogravimetric analysis (TGA) in the laboratory of Technical University of Denmark (DTU) with the same biochar obtained in the previous experiments at TU Wien. The experiments with $\mathrm{H}_{2}$ are avoided due to safety reasons of handling $\mathrm{H}_{2}$ at high temperatures in the laboratory and its reducing environment in the TGA and possible harms to the sensors.

To measure the reactivity of char, a sample is loaded in the crucible of TGA, heated up to the peak temperature at which the reactivity is investigated $\left(650,750,850{ }^{\circ} \mathrm{C}\right)$ with the heating rate of $20 \mathrm{~K} / \mathrm{min}$ in an inert atmosphere with $\mathrm{N}_{2}$ gas to evaporate the moisture in the char and release the remaining volatiles, then the gas is switched to $\mathrm{CO}_{2}$ and the sample is being held for 30 minutes to assess its reactivity over time. This residence time is in the same range for char in the GR during experiments according to IPSEpro data.

The char is not supposed to contain any moisture since it is produced at a temperature above 650 ${ }^{\circ} \mathrm{C}$, but in the process of collecting, sampling and transporting, an average amount of $0.08 \%$ of moisture content was adsorbed and observed in the test runs. The char samples also showed a volatile content of about $2.7 \%$.

One example of the mass loss curve and its derivative as a function of time during the TGA test run of char with $\mathrm{CO}_{2}$ is reported in Figure 8. In this test run, the peak temperature is $850{ }^{\circ} \mathrm{C}$. The maximum conversion rate is noticed at the beginning of the reaction and varied between 0.2 and $0.3 \% / \mathrm{min}$ from $650{ }^{\circ} \mathrm{C}$ to $850^{\circ} \mathrm{C}$.

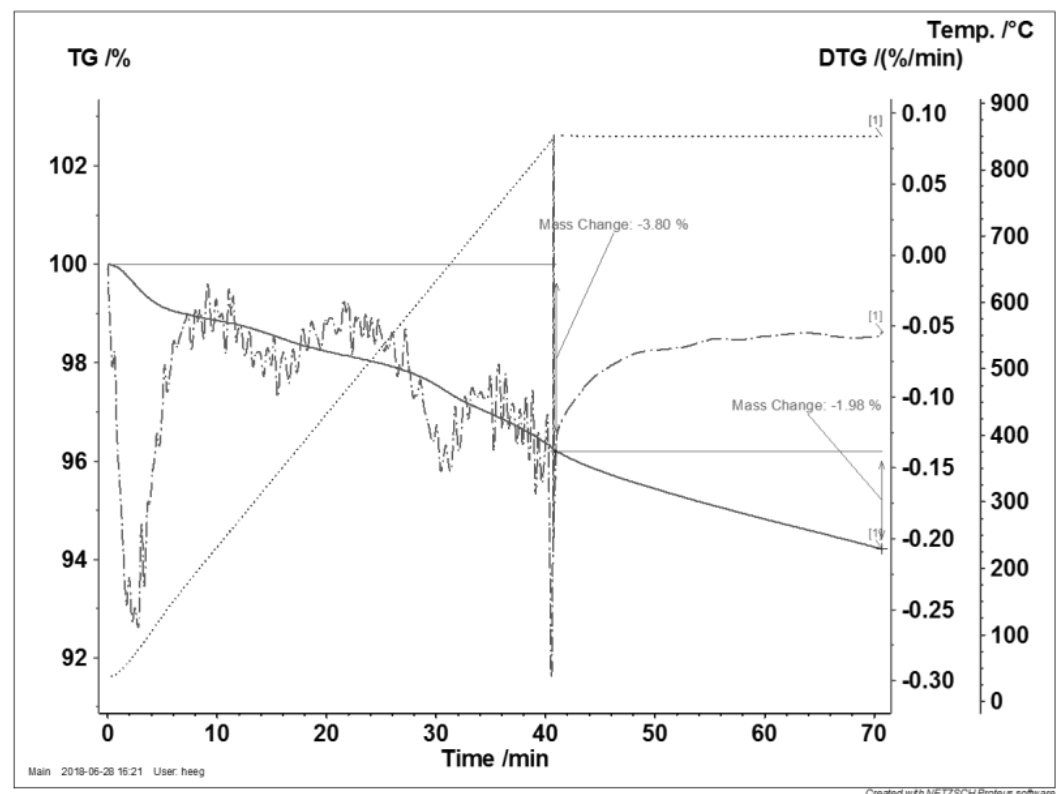

Figure 8 Mass loss curve and its derivative from the char reactivity test run with $\mathrm{CO}_{2}$ in $\mathrm{TGA}^{\mathrm{at}} 850{ }^{\circ} \mathrm{C}$ 
The same approach was adopted to measure the char reactivity with steam. The results show a much higher reactivity between char and steam if to compared to that with char and $\mathrm{CO}_{2}$ which is in agreement with literature data.

The experiments with steam were conducted in a macro TGA where more fluctuations in the mass loss curve was noticed. The resulted curve has been smoothed and the fluctuations have been taken out and one example is reported in the Figure 9 and Figure 10.

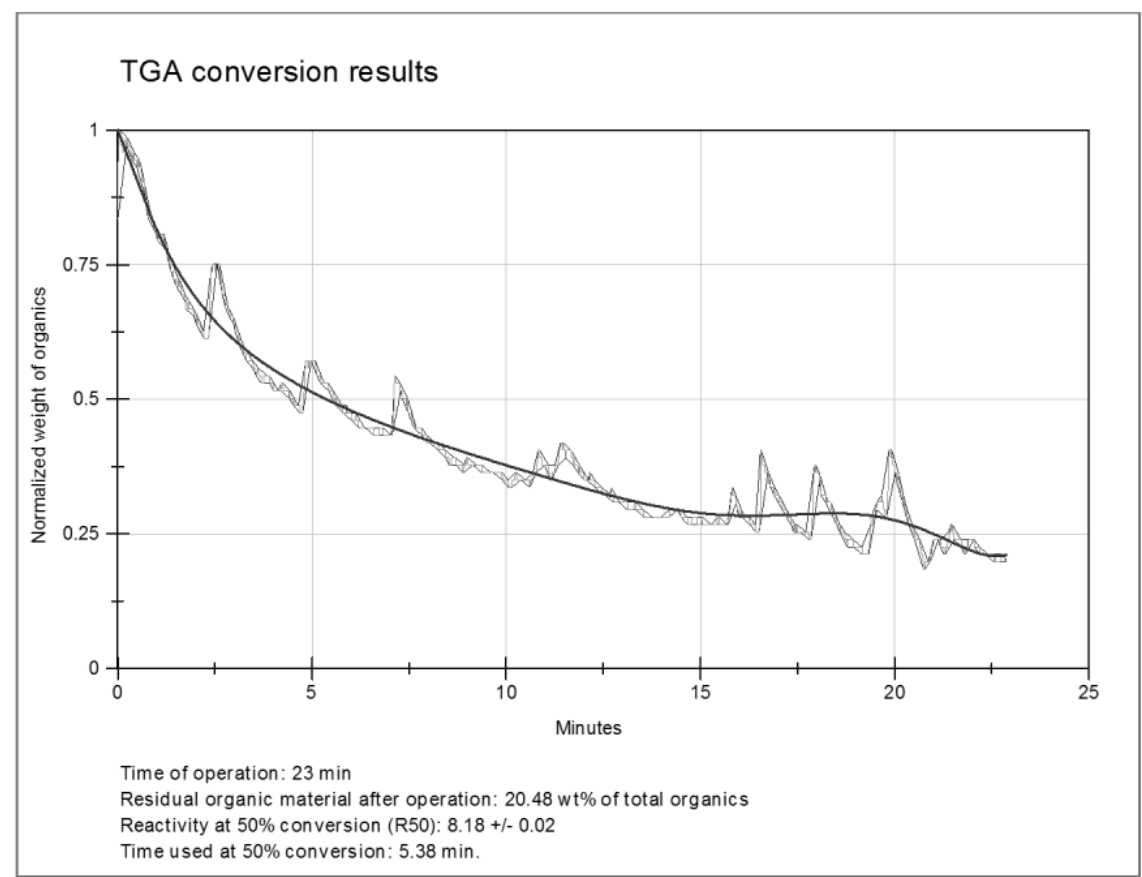

Figure 9 Mass loss curve from the char reactivity test run with $\mathrm{H}_{2} \mathrm{O}$ in macro TGA at $850{ }^{\circ} \mathrm{C}$

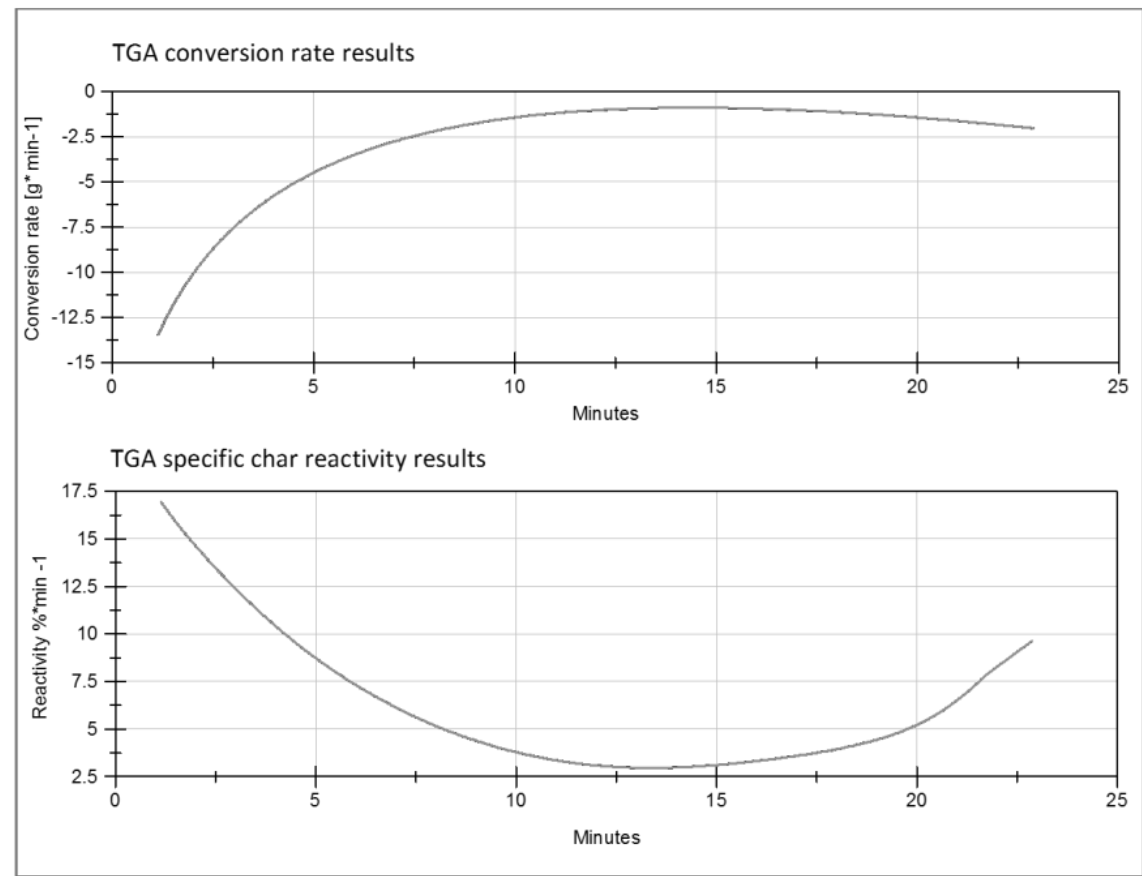

Figure 10 Reactivity \%/min and conversion rate $\mathrm{g} / \mathrm{min}$ from the char reactivity test run with $\mathrm{H}_{2} \mathrm{O}$ in macro TGA at $850{ }^{\circ} \mathrm{C}$ 
To implement the char reactivity equations in the ASPEN plus simulator, further steps were considered. Based on the carbon mass balance over the GR, the unconverted carbon that goes to the $\mathrm{CR}$ is estimated by calculating the unconverted char, by using the correlation of $\mathrm{CHO}$ composition in the char, according to the Figure 4.

The difference between this value and the char yield, based on the calculations reported in Figure 5 indicates the amount of char that is gasified with $\mathrm{H}_{2} \mathrm{O}, \mathrm{CO}_{2}$ and $\mathrm{H}_{2}$ at a certain temperature inside the GR.

The understanding of the char reactivity with $\mathrm{H}_{2} \mathrm{O}$ and $\mathrm{CO}_{2}$ is not enough to calculate the amount of char gasified with these gases and the effective residence time of the char in the bubbling bed of the GR needs to be considered as well. From the experiments, the circulation rate of the bed material is between 3 and 4 cycles per hour which indicates a residence time between 15 to 20 minutes. A fraction of this time is spent in the loop seals and the combustor. Since the combustor is working in a fast fluidization state, an effective residence time of 12 minutes is needed to the char to pass through the bubbling bed of the GR. At this point, the amount of gasified char and the fractional conversion with $\mathrm{H}_{2} \mathrm{O}$ and $\mathrm{CO}_{2}$ are defined, and the difference between the total gasified char, and the fraction which is converted with $\mathrm{H}_{2} \mathrm{O}$ and $\mathrm{CO}_{2}$ can indicate the conversion of char with $\mathrm{H}_{2}$. Based on this information and assuming that the ash is always inert throughout the process, the char-gasification block (CHARREAC) in the ASPEN plus is completely defined.

\section{Water-gas shift reaction}

The most important homogeneous reaction in the process of steam gasification is the water-gas shift reaction (WGSR). According to different studies [34] this reaction can easily reach the equilibrium at high temperature with about 1 second of residence time [35]. There are various kinetic models available for this reaction, but they are mostly developed in presence of different catalysts [36]. Here, for the sake of simplicity, an equilibrium reactor (RGIBS) is used for this reaction. At equilibrium conditions, all of $\mathrm{CH}_{4}$ and $\mathrm{C}_{2} \mathrm{H}_{4}$ reacts with steam and turns into $\mathrm{CO}$ and $\mathrm{CO}_{2}$, and then this approach will bring conspicuous errors to the results. From the experimental results one can notice that the amount of $\mathrm{CH}_{4}$ and $\mathrm{C}_{2} \mathrm{H}_{4}$ varies between 2 and 14\% of the dried product gas. To overcome this discrepancy, these compounds are set to be inert in the WGSR reactor. But, in this case, it can be noticed that equilibrium WGSR reactor convert only a very small fraction of CO. Therefore, via another ASPEN plus calculator, the fractional conversion of $\mathrm{CO}$ is tuned by using the gas composition. The deviation from the equilibrium is calculated from the simulation and experimental results and compared with equilibrium constant from different models $[37,38,39,40]$. Figure 11 shows that different models predict the equilibrium for WGSR somewhere between 820 and $830{ }^{\circ} \mathrm{C}$. The deviation from equilibrium of WGSR is calculated from measurements and the simulation and as can be seen in the Figure 12. Around $800{ }^{\circ} \mathrm{C}$ WGSR is very close to the equilibrium in agreement with the prediction of various models [40]. 


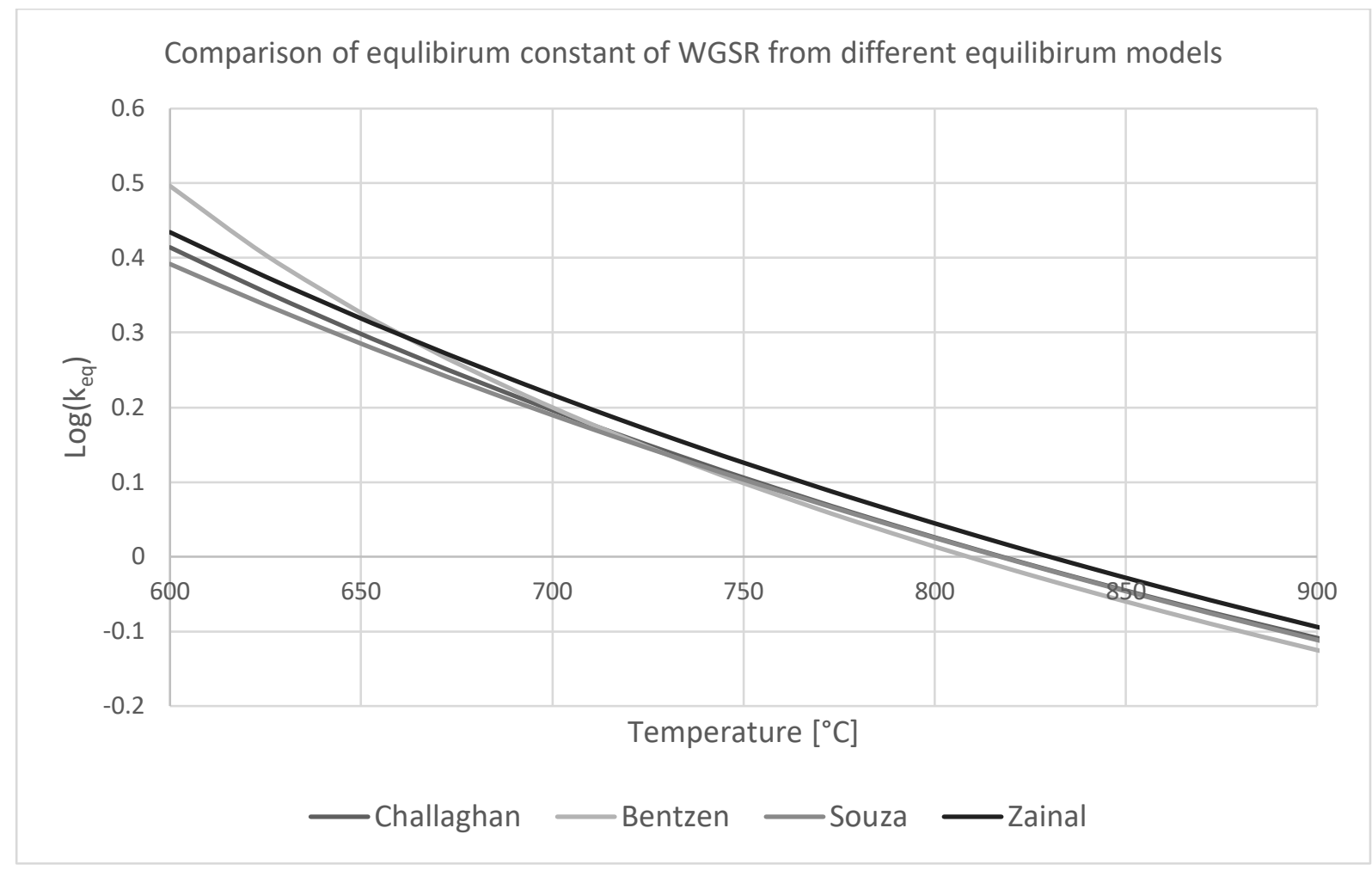

Figure 11 Equilibrium constant of WGSR from different proposed models

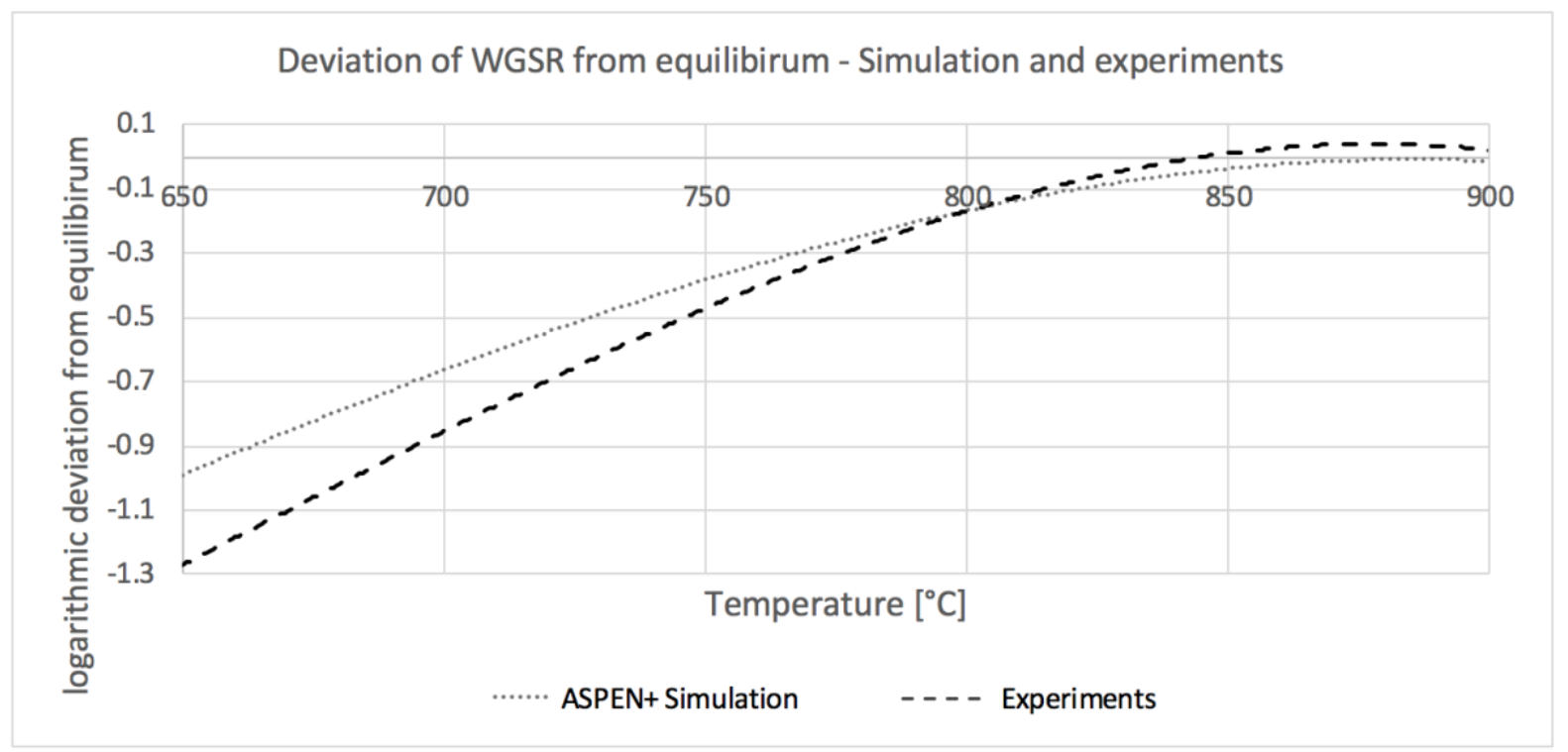

Figure 12 Logarithmic deviation from WGSR equilibrium in experimental and simulation results

\section{Flowsheet in ASPEN plus}

The flowsheet shown in Figure 13 represents the implementation of all the above-mentioned models in the ASPEN plus simulator. Biomass, after being fed to the system is dried by the "DRYER" block and the moisture content of the biomass is updated in its proximate analysis via a calculator block. Then, the dry biomass stream is separated from the evaporated moisture and sent to the "DECOMPOSE" block to be turned into the pyrolysis products using the empirical correlations and the calculations mentioned previously. The correlations and atom/energy balance equations are written in a fortran file and implemented in the model. After 
the pyrolysis the streams are separated into the solid fraction (char and ash), volatiles $\left(\mathrm{H}_{2}, \mathrm{CO}\right.$, $\left.\mathrm{CO}_{2}, \mathrm{CH}_{4}, \mathrm{C}_{2} \mathrm{H}_{4}\right)$ and the liquids (Tar $\left\{\mathrm{C}_{6} \mathrm{H}_{10} \mathrm{O}_{5}, \mathrm{C}_{2} \mathrm{H}_{4} \mathrm{O}_{2}, \mathrm{C}_{5} \mathrm{H}_{4} \mathrm{O}_{2}, \mathrm{C}_{6} \mathrm{H}_{5} \mathrm{OH}\right\}$ and pyrolytic water). Tars are cracked and reformed with steam in another RGIBBS reactor "TARCRACK" block and the products are sent with other components to the reactor "CHARREAC". In this block, a fraction of the char is converted with $\mathrm{H}_{2} \mathrm{O}, \mathrm{CO}_{2}$ and $\mathrm{H}_{2}$. The unconverted char is extracted from the stream and then sent to the CR. Finally, all the gas species are sent to the water gas-shift reactor (WGSR), imposing that $\mathrm{CH}_{4}$ and $\mathrm{C}_{2} \mathrm{H}_{4}$ are inert and conversion of $\mathrm{CO}$ in the WGSR must be tuned over the range of the temperature.

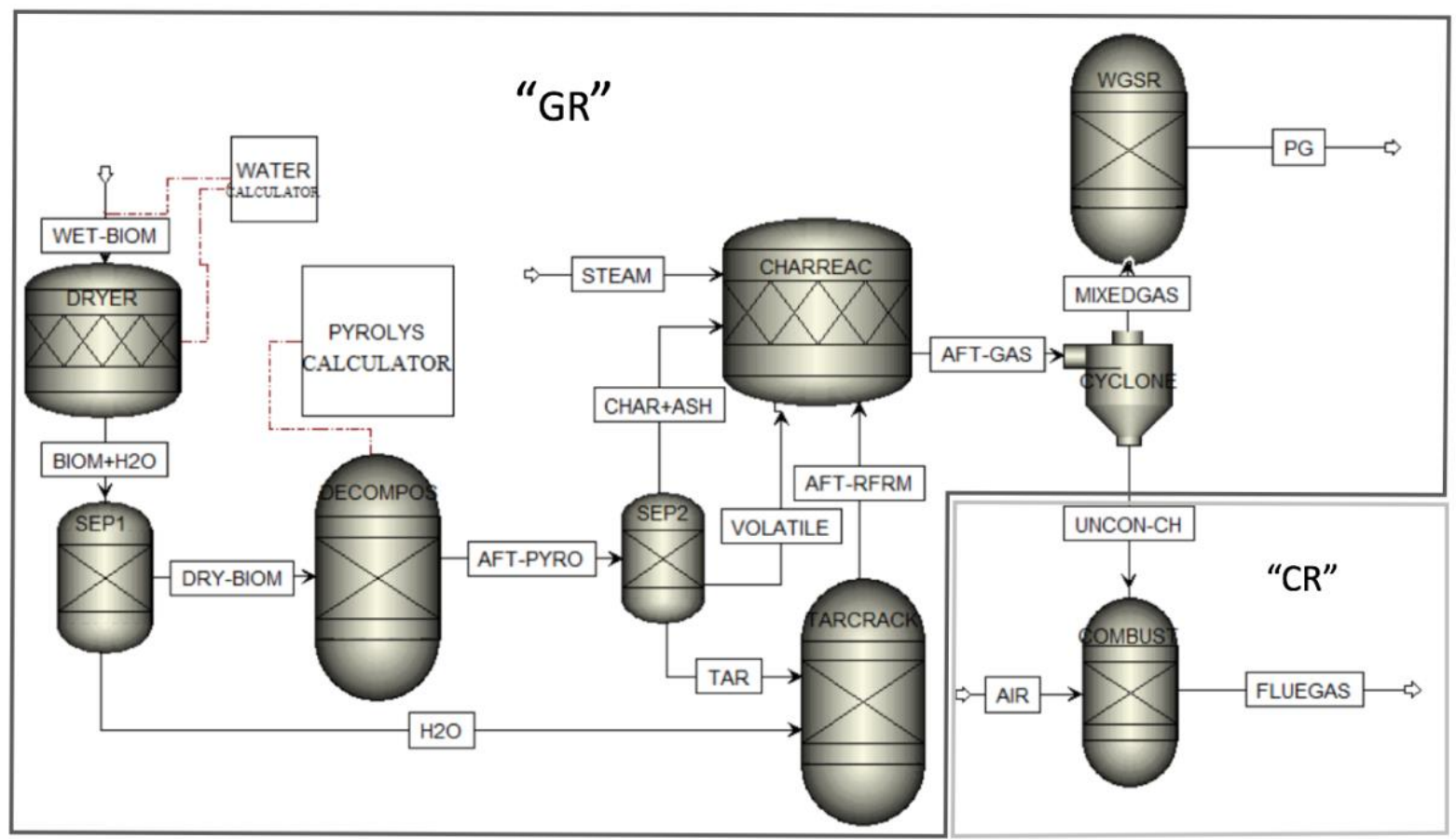

Figure 13 Simulation procedure of the steam gasification process from DFB gasifier of TU Wien in ASPEN plus

\section{RESULT AND DISCUSSION}

The experimental and simulation results of the product gas composition in function of temperature are shown in Figure 14. The dots refer to the experimental results and the solid lines indicate the simulation. After pyrolysis, the yield of both $\mathrm{H}_{2}$ and $\mathrm{CO}$ increases with temperature, and after introducing the steam to fluidize the bed, there is always enough $\mathrm{H}_{2} \mathrm{O}$ for the WGSR. This can easily explain the higher hydrogen productivity when increasing the temperature. The WGSR is slightly exothermic and thermodynamically more favourable at higher temperature even if the reaction kinetic is slower [42]. When increasing the temperature, the reverse WGSR occurs in parallel and finally at about $830{ }^{\circ} \mathrm{C}$, the reverse reaction exceeds. This explains the minimum of $\mathrm{CO}$ around this temperature in the results. At higher temperature, the $\mathrm{CO}$ content starts to increase, and the $\mathrm{CO}_{2}$ content will decrease with increasing gasification temperature. This $\mathrm{CO}$ minimum (respectively $\mathrm{CO}_{2}$ maximum) was previously reported in different studies [40] and [41] but never been predicted by the simulation. The yield of $\mathrm{CH}_{4}$ and $\mathrm{C}_{2} \mathrm{H}_{4}$ from pyrolysis increase with temperature. Also, these compounds are produced when the char reacts with $\mathrm{H}_{2}$ or when the tar are cracked and reformed by either steam or $\mathrm{CO}_{2}$. In the equilibrium model, $\mathrm{CH}_{4}$ and $\mathrm{C}_{2} \mathrm{H}_{4}$ are predicted to have negligible amount in the producer gas, but the ratio of $\mathrm{H}_{2} \mathrm{O} / \mathrm{CO}>3$ can drastically inhibit the methanation [45] and that explains why we still notice some percentage of these compounds in the product gas. 
The discrepancy between the experimental results with simulation can be due to neglecting some side reactions as well as neglecting the kinetics of the tar reactions or dry reforming that could produce more of $\mathrm{CH}_{4}$ and $\mathrm{C}_{2} \mathrm{H}_{4}$.

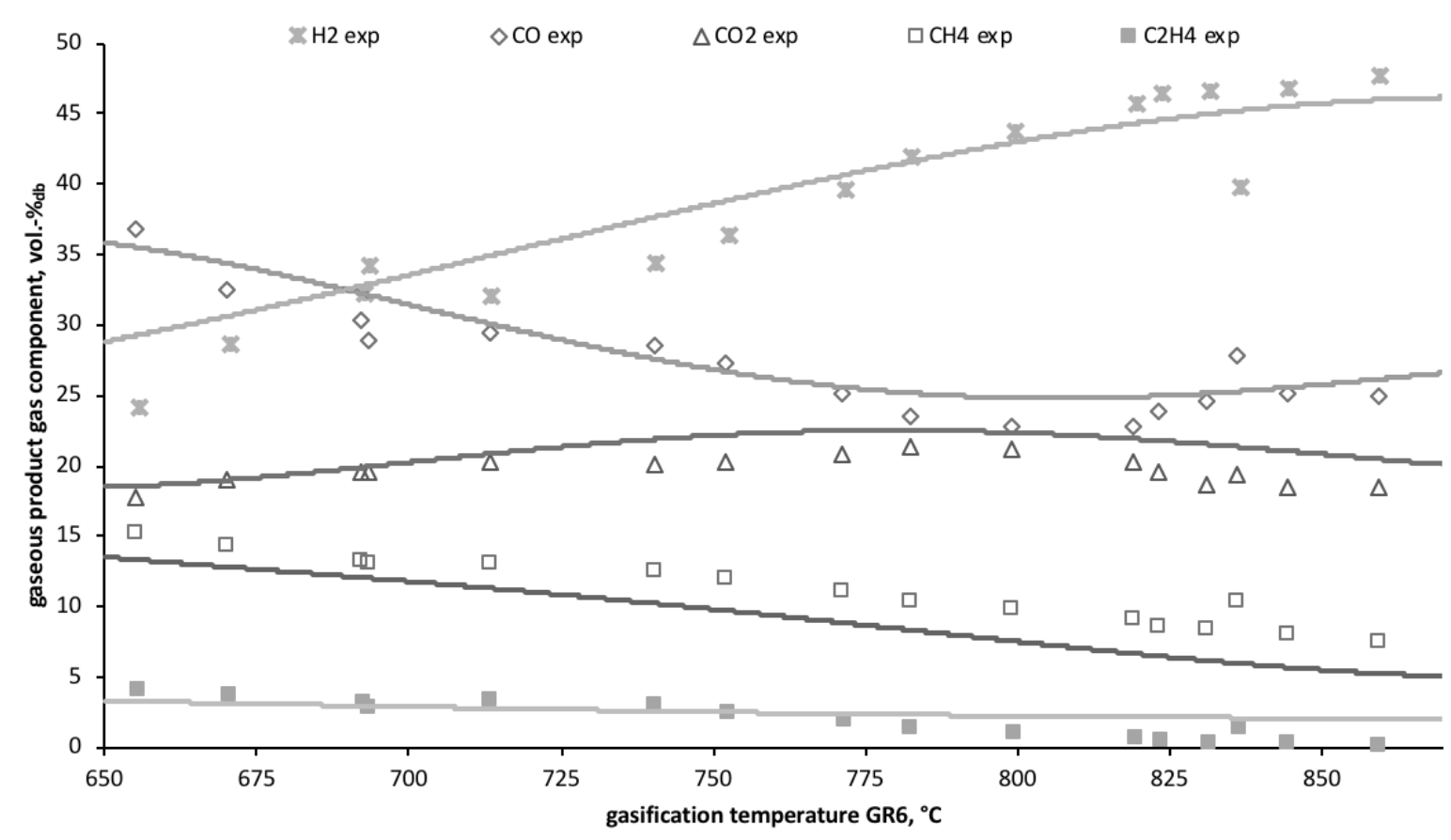

Figure 14 Comparison of product gas composition between experimental measurements and simulation results from ASPEN plus

In Figure 15 the results are presented in a different perspective. The horizontal and vertical axis represent experimental and simulation results, and the numbers $1,2,3,4,5$ represent the temperatures of $650,700,750,800$ and $850{ }^{\circ} \mathrm{C}$ respectively. A ratio between simulation and experimental results are reported for the gas composition at above-mentioned temperatures. As it can be noticed, everything coincides in a margin of less than $10 \%$ error except few cases of $\mathrm{CH}_{4}$ and the sum of $\mathrm{CH}_{4}$ and $\mathrm{C}_{2} \mathrm{H}_{4}$. Even though the trend between simulation and measurement data of $\mathrm{CH}_{4}$ and $\mathrm{C}_{2} \mathrm{H}_{4}$ are the same, since they have lower values in the gas composition, even $1 \%$ difference in the value can results to a large relative error above $10 \%$. This can be only improved by implementing the kinetics of tar cracking and their dry reforming. 


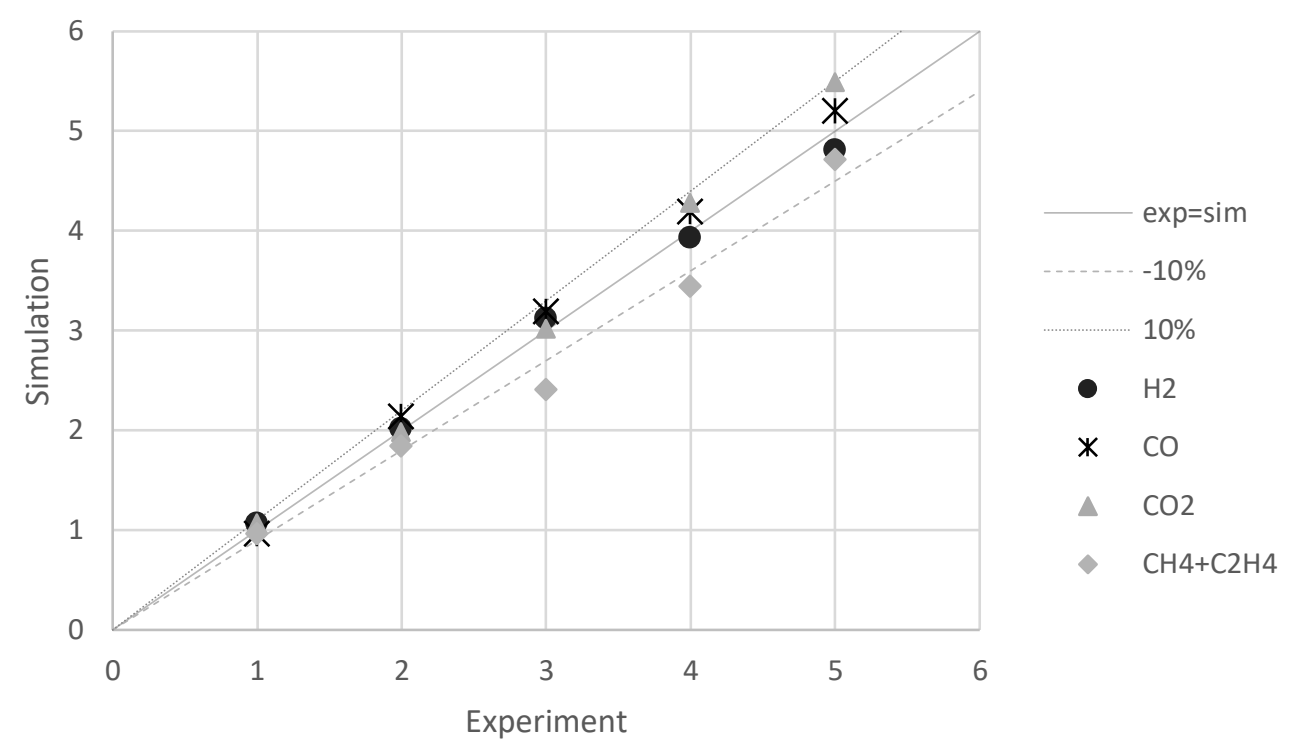

Figure 15 Comparison between the results of simulation model and measurement data of the steam gasification of softwood pellets with olivine sand as bed material in the $100 \mathrm{~kW}$ DFB gasifier

\section{CONCLUSION}

A methodology is developed to model a DFB gasifier using ASPEN plus simulator coupled with internal Fortran files separately reproducing pyrolysis including an extensive investigation on char reactivity. The method is based on separating the main reactions -pyrolysis, char gasification, waster-gas shift reaction, tar formation and conversion, and char combustion- in different reactors.

Pyrolysis product yields (char, volatiles, pyrolytic water, tar species) and their composition are implemented in Fortran file and coupled with the ASPEN plus simulator. Even though the reactor for water-gas shift reactor is chosen to be an equilibrium one, a semi detailed kinetic approach based on the experimental measurements is used to tune the $\mathrm{CO}$ conversion.

This method allows having an insight on the mechanism of the reactions that occur inside the gasifier as a result of suitable pyrolysis correlation and semi-detailed kinetic approach of WGSR.

More investigation is required to introduce the fully detailed kinetic of WGSR in both forward and reverse direction; implementing of kinetics of tar cracking/reforming can enhance the predication of gas composition and can include the remaining tar based on the operational condition in the product gas; implementing other parallel reactions can close the gap between experimental measurements and simulation results specially at lower temperatures.

This model can be used to predict future test runs, and by changing the bed material, the effect of catalytic conversion can be assessed. This model can be also used to optimize the performance of the plant and finally with the acquired knowledge from the sub-processes in the system, improvement of current designs or make innovative designs are feasible.

Furthermore, this model can replace the classical big black box mass and energy balance models with the capability of analysing all the sub-processes in between and make optimizing of the operational condition more efficient. 


\section{NOMENCLATURE}

\begin{tabular}{|c|c|}
\hline$Y_{i, R}$ & $\begin{array}{l}\text { yield of ith product, dry ash-free fuel basis ( } \mathrm{kg} \mathrm{i} / \mathrm{kg} \text { dry ash-free fuel } \mathrm{F} \text { ), } \\
\text { dry fuel basis }(\mathrm{kg} \mathrm{i} / \mathrm{kg} \text { dry fuel } \mathrm{R}) \text { or as-received fuel basis }(\mathrm{kg} \mathrm{i} / \mathrm{kg} \text { as- } \\
\text { received fuel } \mathrm{K})\end{array}$ \\
\hline$Y_{j, F}, Y_{j, R}, Y_{j, K}$ & $\begin{array}{l}\text { mass fraction of jth element in fuel, dry ash-free fuel basis }(\mathrm{kg} \mathrm{j} / \mathrm{kg} \text { dry } \\
\text { ash-free fuel F), dry fuel basis }(\mathrm{kg} \mathrm{j} / \mathrm{kg}\end{array}$ \\
\hline & dry fuel $\mathrm{R}$ ) or as-received fuel basis ( $\mathrm{kg}$ i/kg as-received fuel $\mathrm{K}$ ) \\
\hline$Y_{j, i}$ & mass fraction of $\mathrm{j}_{\mathrm{th}}$ element in ith product, $\mathrm{kg} \mathrm{j} / \mathrm{kg} \mathrm{i}$ \\
\hline $\mathrm{Y}_{\mathrm{a}, \mathrm{F}}, \mathrm{Y}_{\mathrm{a}, \mathrm{R}}, \mathrm{Y}_{\mathrm{a}, \mathrm{K}}$ & $\begin{array}{l}\text { ash content in fuel, dry ash-free fuel basis ( } \mathrm{kg} \text { ash } / \mathrm{kg} \text { dry ash-free fuel F), } \\
\text { dry fuel basis ( } \mathrm{kg} \text { ash/kg dry fuel } \mathrm{R} \text { ) or as-received fuel basis ( } \mathrm{kg} \text { ash } / \mathrm{kg} \\
\text { as-received fuel } \mathrm{K} \text { ) }\end{array}$ \\
\hline$Y_{\mathrm{a}, \mathrm{i}}$ & ash content in ith product, $\mathrm{kg}$ ash $/ \mathrm{kg} \mathrm{i}$ \\
\hline$Y_{M, F}, Y_{M, R}, Y_{M, K}$ & $\begin{array}{l}\text { moisture content in fuel, dry ash-free fuel basis ( } \mathrm{kg} \text { moisture } / \mathrm{kg} \text { dry ash- } \\
\text { free fuel F), dry fuel basis (kg moisture/kg dry fuel R) or as-received fuel } \\
\text { basis ( } \mathrm{kg} \text { moisture } / \mathrm{kg} \text { as-received fuel } \mathrm{K} \text { ) }\end{array}$ \\
\hline II, & in $i_{\text {th }}$ product, $\mathrm{kg}$ moisture $/ \mathrm{kg} \mathrm{i}$ \\
\hline $\mathrm{HV}$ & lower heating value of $\mathrm{ith}_{\text {th }}$ product, $\mathrm{MJ} / \mathrm{kg} \mathrm{i}$ \\
\hline & eactor) peak temperature, ${ }^{\circ} \mathrm{C}$ \\
\hline & are of the correlation coefficient \\
\hline
\end{tabular}

\section{REFERENCES}

1. Larsson, A.; Seemann, M.; Neves, D.; Thunman, H. Evaluation of Performance of IndustrialScale Dual Fluidized Bed Gasifiers Using the Chalmers 2-4-MWth Gasifier. Energy Fuels 2013, 27, 6665-6680.

2. Borello et al., Modeling and experimental study of a small scale olive pomace gasifier for cogeneration: Energy and profitability analysis, Energies, 2017

3. Puig-Arnavat, M., Bruno, J. C., \& Coronas, A. (2010). Review and analysis of biomass gasification models. Renewable and Sustainable Energy Reviews, 14(9), 2841-2851. https://doi.org/10.1016/j.rser.2010.07.030

4. Abdelouahed, L., Authier, O., Mauviel, G., Corriou, J. P., Verdier, G., \& Dufour, A. (2012). Detailed modeling of biomass gasification in dual fluidized bed reactors under aspen plus. Energy and Fuels, 26(6), 3840-3855. https://doi.org/10.1021/ef300411k

5. Neves, D., Thunman, H., Matos, A., Tarelho, L., \& Gómez-barea, A. (2011). Characterization and prediction of biomass pyrolysis products. Progress in Energy and Combustion Science, 37(5), 611-630. https://doi.org/10.1016/j.pecs.2011.01.001

6. Report, P. (2016). Technical Report of Scientific Experimental Research Steam gasification of EXHAUSTED OLIVE POMACE with a dual fluidized bed pilot plant at TU Wien (Vol. 605357).

7. Schmid, J.C., Wolfesberger, U., Koppatz, S., Pfeifer, C., Hofbauer, H., 2012, "Variation of Feedstock in a Dual Fluidized Bed Steam Gasifier - Influence on Product Gas, Tar Content and Composition", Environmental Progress \& Sustainable Energy, Vol. 31 (2), pp. 205-2015, July 2012, Wiley, doi.org/10.1002/ep.11607

8. Schmid, J.C., 2014, "Development of a novel dual fluidized bed gasification system for increased fuel flexibility", doctoral thesis, Vienna University of Technology, ISBN 978-39502754-6-9 
9. Benedikt, F., Schmid, J.C., Fuchs, J., Mauerhofer, A., Müller, S., Hofbauer, H., 2018, "Fuel Flexible Gasification with an Advanced $100 \mathrm{~kW}$ Dual Fluidized Bed Steam Gasification Pilot Plant", Energy, Vol.xxx, pp. xxx-xxx, doi.org/10.1016/j.energy.2018.08.146

10.Pröll, T.; Hofbauer, H. Development and Application of a Simulation Tool for Biomass Gasification Based Processes. Int. J. Chem. React. Eng. 2008, 6, Article 89.

11.Prins, M. J., Ptasinski, K. J., \& Janssen, F. J. J. G. (2003). Thermodynamics of gas-char reactions: First and second law analysis. Chemical Engineering Science, 58(3-6), 1003-1011. https://doi.org/10.1016/S0009-2509(02)00641-3

12.Pearson, R. G., \& Williams, E. L. (1987). A comparison of heterogeneous and homogeneous kinetics in the formation of a polyurethane. Journal of Polymer Science Part A: Polymer Chemistry, 25(2), 565-573. https://doi.org/10.1002/pola.1987.080250210

13.Pala, L. P. R., Wang, Q., Kolb, G., \& Hessel, V. (2017). Steam gasification of biomass with subsequent syngas adjustment using shift reaction for syngas production: An Aspen Plus model. Renewable Energy, 101, 484-492. https://doi.org/10.1016/j.renene.2016.08.069

14.Milne, T. A., Evans, R. J., \& Abatzaglou, N. (1998). Biomass Gasifier "“Tars"”: Their Nature, Formation, and Conversion, (November). https://doi.org/10.2172/3726

15.Babu, B. V., \& Chaurasia, A. S. (2004). Dominant design variables in pyrolysis of biomass particles of different geometries in thermally thick regime. Chemical Engineering Science, 59(3), 611-622. https://doi.org/10.1016/j.ces.2003.10.014

16.Di Blasi C, Branca C, Santoro A, Hernandez EA. Pyrolytic behavior and products of some wood varieties. Combust Flame 2001;124:165e77

17.Scott DS, Piskorz J, Radlein D. Liquid products from the continuous flash pyrolysis of biomass. Ind Eng Chem Process Des Dev 1985;24:581e8.

18. Scott DS, Piskorz J, BergougnouMA, Graham R, Overend RP. The role of temper- ature in the fast pyrolysis of cellulose andwood. Ind ChemRes 1988;27:8e15.

19.Funazukuri T, Hudgins RR, Silveston PL. Correlation of volatile products from fast cellulose pyrolysis. Ind Eng Chem Process Des Dev 1986;25:172e81

20.Wang X, Kersten SRA, Prins W, van Swaaij WPM. Biomass pyrolysis in fluidized bed reactor. Part 2: experimental validation of model results. Ind Eng Chem Res 2005;44:8786e95.

21.Zanzi R, Sjöström K, Björnbom E. Rapid pyrolysis of agricultural residues at high temperature. Biomass \& Bioenergy 2002;23:357e66.

22.Encinar JM, González JF, González J. Fixed-bed pyrolysis of Cynara cardunculus L. Product yields and compositions. Fuel Process Technol 2000;68:209e22.

23.Dupont C, Commandré JM, Gauthier P, Boissonnet G, Salvador S, Schweich D. Biomass pyrolysis experiments in an analytical entrained flow reactor between $1073 \mathrm{~K}$ and $1273 \mathrm{~K}$. Fuel 2008;87:1155e64

24.Fagbemi L, Khezami L, Capart R. Pyrolysis products from different biomasses: application to the thermal cracking of tar. Appl Energy 2001;69:293e306.

25.Di Blasi C, Signorelli G, Di Russo C, Rea G. Product distribution from pyrolysis of wood and agricultural residues. Ind Eng Chem Res 1999;38:2216e24

26. Horne PA, Williams T. Influence of temperature on the products from the flash pyrolysis of biomass. Fuel 1996;75:1051e9.

27. Aguado R, Olazar M, José MJS, Aguirre G, Bilbao J. Pyrolysis of sawdust in a conical spouted bed reactor. Yields and product composition. Ind Eng Chem Res 2000;39:1925e33

28.Demirbas A. Effect of temperature on pyrolysis products from four nut shells. J Anal Appl Pyrolysis 2006;76:285e9.

29.Schmid, J. C., Müller, S., \& Hofbauer, H. (2016). First Scientific Results with the Novel Dual Fluidized Bed Gasification Test Facility at TU Wien. 24th European Biomass Conference and Exhibition, 2-6. https://doi.org/10.5071/24thEUBCE2016-2CV.3.16 
30.Ahrenfeldt, J., Henriksen, U., Gøbel, B., \& Fjellerup, J. (2005). Experimental Characterisation of Residual-Tar in Wood Char.

31.Paviet, F., Chazarenc, F., \& Tazerout, M. (2009). Thermo Chemical Equilibrium Modelling of a Biomass Gasifying Process Using ASPEN PLUS. International Journal of Chemical Reactor Engineering, 7(1). https://doi.org/10.2202/1542-6580.2089

32.Klose, W., \& Wölki, M. (2005). On the intrinsic reaction rate of biomass char gasification with carbon dioxide and steam. Fuel, 84(7-8), 885-892. https://doi.org/10.1016/j.fuel.2004.11.016

33.Kramb, J., Konttinen, J., Gómez-Barea, A., Moilanen, A., \& Umeki, K. (2014). Modeling biomass char gasification kinetics for improving prediction of carbon conversion in a fluidized bed gasifier. Fuel, 132, 107-115. https://doi.org/10.1016/j.fuel.2014.04.014

34.Smith R J, B., Loganathan, M., \& Shantha, M. S. (2010). A Review of the Water Gas Shift Reaction Kinetics. International Journal of Chemical Reactor Engineering, 8(1). https://doi.org/10.2202/1542-6580.2238

35.Wheeler, C., Jhalani, A., Klein, E. J., Tummala, S., \& Schmidt, L. D. (2004). The water-gasshift reaction at short contact times. Journal of Catalysis, 223(1), 191-199. https://doi.org/10.1016/j.jcat.2004.01.002

36.Lima, D. F. B., Zanella, F. A., Lenzi, M. K., \& Ndiaye, P. M. (20012). Modeling and Simulation of Water Gas Shift Reactor: An Industrial Case. Cdn.Intechopen.Com. Retrieved from http://cdn.intechopen.com/pdfs/34193/InTechModeling and_simulation_of_water_gas_shift_reactor_an_industrial_case.pdf

37.Zainal, Z.A.; Ali, R.; Lean, C.H.; Seetharamu, K.N. (2001) Prediction of performance of a downdraft gasifier using equilibrium modeling for different biomass materials. Energy Conversion and Management 42: 1499-515.

38.de Souza-Santos, M. L. (1989) Comprehensive Modelling and Simulation of Fluidized-Bed Boilers and Gasifiers. Fuel, 68: 1507-21.

39.Bentzen, J.D.; Brandt, P.; Gøbel, B.; Hansen, C.H.; Henriksen, U. (1998) 100kW Totrinsforgasningsanlæg på DTU Resultater til og med foråret 1998, ET-ES 98-11, Institut for Energiteknik, Technical University of Denmark, Denmark.

40.Callaghan, C. A. (2006). Kinetics and Catalysis of the Water-Gas-Shift Reaction: A Microkinetic and Graph Theoretic Approach. Department of Chemical Engineering, Ph. D. The, 400.

41.Demirel, E., \& Azcan, N. (2012). Thermodynamic Modeling of Water-Gas Shift Reaction in Supercritical Water. Proceedings of the World Congress on Engineering and Computer Science, II, 24-27.

42.Wheeler, C., Jhalani, A., Klein, E. J., Tummala, S., \& Schmidt, L. D. (2004). The water-gasshift reaction at short contact times. Journal of Catalysis, 223(1), 191-199. https://doi.org/10.1016/j.jcat.2004.01.002

43.Suwatthikul, A., Limprachaya, S., Kittisupakorn, P., \& Mujtaba, I. M. (2017). Simulation of steam gasification in a fluidized bed reactor with energy self-sufficient condition. Energies, 10(3), 1-15. https://doi.org/10.3390/en10030314

44.Waheed, Q. M. K., Wu, C., \& Williams, P. T. (2016). Hydrogen production from high temperature steam catalytic gasification of bio-char. Journal of the Energy Institute, 89(2), 222230. https://doi.org/10.1016/j.joei.2015.02.001

45.Gao, J., Wang, Y., Ping, Y., Hu, D., Xu, G., Gu, F., \& Su, F. (2012). A thermodynamic analysis of methanation reactions of carbon oxides for the production of synthetic natural gas. RSC Advances, 2(6), 2358. https://doi.org/10.1039/c2ra00632d 